Western Washington University

Western CEDAR

\title{
Reconciling Environmentalism and the Left: Perspectives on Democracy and Social Justice in British Columbia's Environmental Movement
}

Donald K. Alper

Western Washington University, don.alper@wwu.edu

Debra J. Salazar

Western Washington University, debra.salazar@wwu.edu

Follow this and additional works at: https://cedar.wwu.edu/politicalscience_facpubs

Part of the Political Science Commons

\section{Recommended Citation}

Alper, Donald K. and Salazar, Debra J., "Reconciling Environmentalism and the Left: Perspectives on Democracy and Social Justice in British Columbia's Environmental Movement" (2002). Political Science Faculty Publications. 4.

https://cedar.wwu.edu/politicalscience_facpubs/4 


\title{
Reconciling Environmentalism and the Left: Perspectives on Democracy and Social Justice in British Columbia's Environmental Movement
}

\author{
Debra J. Salazar Western Washington University \\ DonAld K. Alper Western Washington University
}

From their efforts to stop the clubbing of harp seal pups to blockades of ancient forests, Canadian environmental activists have sometimes physically confronted working people as they attempt to earn a living. Indeed, the history of the environmental movement has been marked by conflict with labour. Wood products companies have exploited this conflict by working with unions to frame forest management battles as jobs versus amenities, working people against "cappuccino suckers." ${ }^{1}$ Environmentalists are portrayed by their opponents as elitists intent on preserving their wilderness playgrounds at the expense of rural communities. This opposition of environmentalists' and workers' aims divides two constituencies that are central to contemporary social democratic politics, ${ }^{2}$ and is exemplary

1 Jeremy Wilson examines the jobs versus environment debate in the BC forest conflict in Talk and Log: Wilderness Politics in British Columbia (Vancouver: University of British Columbia Press, 1998).

2 Mae Burrows outlines a strategy to support alliances between labour and environmentalists in "Allied Forces: Unions and Environmentalists Can Work Together for Jobs and Ecological Sustainability," Alternatives 24 (1998), 18-23.

Acknowledgments: Support for this research was provided by a research grant from the Canadian embassy-Government of Canada. The JournAL's reviewers provided useful comments. We thank the many environmental activists who participated in interviews.

Debra J. Salazar, Department of Political Science, Center for Canadian-American Studies, Western Washington University, Bellingham, Washington, USA 98225; salazard@cc.wwu.edu Donald K. Alper, Department of Political Science, Center for Canadian-American Studies, Western Washington University, Bellingham, Washington, USA 98225; alper@cc.wwu.edu 
of more general tensions between environmentalists and other progressive sectors.

Perhaps the common cause of environmentalists, and of others on the left, has been most apparent in the struggles against trade liberalization, one of the key progressive issues of the last decade. Environmentalists have been central players in this battle, mobilizing citizens to oppose unconstrained international trade and investment, arguing that Canadians ought to control the use of their natural resources and the quality of their environment. Labour leaders and social justice advocates have made related arguments about the destructive effects of trade liberalization on wages and working conditions. They predict that the abdication of national sovereignty to multilateral trade institutions will leave workers subject to the whims of investment bankers and result in the migration of capital to countries with low wages and weak regulations, thus pressuring unions and governments in wealthy countries to accept policies and practices that will reduce living standards. Environmentalists join others on the left to argue that trade liberalization undermines democracy.

This argument is very much at the centre of what Habermas has called new politics, an orientation that is not captured by conventional left/right thinking about class conflict and the distribution of wealth. ${ }^{3}$ The environmental movement, along with elements of the women's and peace movements, is exemplary of this new politics. These new social movements have been the primary instruments of new politics and have created new cleavages in Western democracies. In contrast with most older movements, they have challenged the cultural norms rather than the class structures of their societies. ${ }^{4}$ They seek a participatory democratic politics and freedom from the reach of both state and market imperatives. ${ }^{5}$ The focus of new movements is not redistributive policies and class interests, but democracy, personal autonomy and identity. Given this portrayal, conflict between labour and environmentalists is perfectly understandable. Labour is old politics; its aims are squarely redistributive. Environmentalists do not emphasize material well-being; instead of redistributing material wealth, they want to redefine wealth.

One of the dilemmas posed by new politics is how traditional social democratic parties can reconcile the claims (both material and ideal) of the two constituencies. Our purpose in this article is to facilitate this by examining the political ideas of environmentalists, especially those relating to democracy, social justice and nature. We want

3 Jürgen Habermas, "New Social Movements," Telos 49 (1981), 33.

4 Ibid., 33-37; Claus Offe, "New Social Movements: Challenging the Boundaries of Institutional Politics," Social Research 52 (1985), 817-68.

5 Habermas, "New Social Movements," 33-37. 
Abstract. The article examines how political ideas of environmentalists support as well as impede relations between the environmental movement and other progressive movements. This requires examination of the role and meaning of social justice and democracy in the discourse of environmentalism. This study focuses such an examination on a sample of environmental activists in British Columbia. Q methodology is used to discern patterns of association between particular sets of environmental ideas, and beliefs and values related to democracy and social justice. The authors identify four environmental/political perspectives: alienated ecocentrism, civic communitarianism, insider preservationism and green egalitarianism. These perspectives share a perception of justice focused on fair democratic procedures. Fairness is linked to inclusion and equal treatment.

Résumé. Pourquoi les idées politiques des écologistes sont-elles à la fois un facteur de rapprochement et un ferment de discorde entre le mouvement environnementaliste et d'autres mouvements progressistes? Afin de répondre à cette question, cet article analyse la signification qu'accordent les écologistes à la justice sociale et à la démocratie en se référant aux discours de divers groupes environnementalistes de la Colombie Britannique. Il utilise la méthode Q pour identifier les patterns d'association des idées écologistes avec les croyances et valeurs reliées à la démocratie et à la justice sociale. Les auteurs identifient quatre perspectives politiques environnementalistes: l'égocentrisme aliéné, le communautarisme civique, le préservationnisme des initiés et l'égalitarisme vert. Ils montrent que toutes ces perspectives partagent une même conception de la justice : des procédures démocratiques équitables qui accordent un traitement égal à tous les citoyens.

to discover what and how much environmentalists share with the old left, and where they diverge. More importantly, we want to explore how the political ideas of environmentalists might support as well as impede relations between the environmental movement and other progressive movements.

Increasingly, research has examined the relation between environmentalist commitments and broader political orientations among mass publics. ${ }^{6}$ Studies have found a positive relation between environmental concern/values and left/liberal politics and postmaterialism. But little research has examined what environmentalism means for those active in the movement. This article reports findings of a study of the political ideas of environmental activists in British Columbia. The objectives are to discover sets of beliefs and values about politics and the earth that unite activists in the environmental movement, and to identify patterns in the variation in these beliefs and values.

At least since the 1960s, environmentalism has been central to BC politics. Conflicts between environmentalists and labour and other social justice groups have been played out primarily in one of BC's major parties - the New Democratic party-and thus have greatly

6 Donald E. Blake, Neil Guppy and Peter Urmetzer, "Being Green in BC: Public Attitudes towards Environmental Issues," BC Studies 112 (1996-1997), 41-61; and Mebs Kanji, "North American Environmentalism and Political Integration," American Review of Canadian Studies 26 (1996), 183-204. 
influenced electoral and governmental outcomes. The political consequences of these divisions were particularly apparent in 2001, when the Green party won more than 12 per cent of the vote in the BC provincial election by appealing to many traditional NDP voters.

\section{Environmentalism and Environmental Values}

The first step in assessing the political orientation of environmentalists, and of environmentalism as a movement, is to define the focus of analysis. One could define an environmentalist by attitudes, values and beliefs, by identification with the movement, or by behaviour. Our approach has been to rely on the last two. Thus we have selected interviewees based on their self-conscious participation in environmental activism. Further, we define environmental beliefs and values as those held by environmental activists.

Not surprisingly, during the more than two decades of research on environmentalism, analysts have used a variety of measures to characterize popular support for environmental goals and to assess the extent of support for the environmental movement. Attitudes regarding environmental problems have been the most common focus of empirical analysis. Public opinion polls regularly query respondents regarding the seriousness of air and water pollution, global climate change, toxic substances and numerous other environmental concerns. ${ }^{7}$ These studies gauge popular support for environmental goals by the extent and strength of public concern about environmental problems. A second measure is support for environmental policies and programmes. A commonly used question asks respondents to state their position on an appropriate level of public spending for environmental protection. ${ }^{8} \mathrm{~A}$ related item poses a tradeoff (for example, protecting the environment is more important than economic growth) and asks respondents to

7 Riley E. Dunlap, George H. Gallup and Alec M. Gallup, Health of the Planet: A George H. Gallup Memorial Survey (Princeton: Gallup International Institute, 1993); Louis Harris and Humphrey Taylor, "Our Planet-Our Health: Attitudes to Environment," World Health Forum 11 (1990), 32-37; and Larry Pynn, "Environment Tops Poll of Canadians' Concerns," Vancouver Sun, September 21, 1999.

8 Support for spending as an indicator of public environmentalism in the US from the 1970s through the 1980s, and in the Pacific Northwest during the mid-1990s, are used respectively by Robert Emmett Jones and Riley E. Dunlap, "The Social Bases of Environmental Concern: Have They Changed over Time?" Rural Sociology 57 (1992), 28-47; and Richard J. Ellis and Fred Thompson, "Culture and the Environment in the Northwest," American Political Science Review 91 (1997), 885-97. Similarly, Ronald Inglehart uses willingness to contribute money in his cross-national assessment of environmental support, "Public Support for Environmental Protection: Objective Problems and Subjective Values in 43 Societies," PS: Political Science and Politics 28 (1995), 57-72. 
state their level of agreement. ${ }^{9}$ The level of positive affect for environmental organizations and movements is another commonly used measure. ${ }^{10}$

Finally, the strength of environmental beliefs and values and frequency of environmental behaviour are used to measure commitment to environmentalism. Environmental values in particular have drawn the attention of social scientists and theorists from a variety of disciplines and perspectives. Dunlap and Van Liere proposed a set of measures to describe the "new environmental paradigm" (NEP). ${ }^{11}$ The NEP comprises attitudes related to three elements: the fragility of the balance of nature; limits to growth; and the inherent value of plants and non-human animals. Numerous authors have used these and similar measures to assess the extent of environmentalist thinking in populations throughout the world. ${ }^{12}$

A major conclusion of this work is that support for environmental protection is a global phenomenon. But researchers disagree on the social correlates of such support. Some argue that higher levels of environmental support are associated with increasing wealth at the individual or national levels. ${ }^{13}$ Others argue that environmentalism is neither a function of a country's level of economic development, ${ }^{14}$ nor of individual citizen's class status. ${ }^{15}$ These disagreements notwithstanding, environmentalism clearly has affected people's beliefs and values in every region of the world as well as within every social and economic sector of Western industrial societies. Environmental values have influenced profoundly the way citizens think about the relation

9 Herman Bakvis and Neil Nevitte use such an item to gauge the extent of environmental support among the Canadian electorate in "The Greening of the Canadian Electorate: Environmentalism, Ideology, and Partisanship,” in Robert Boardman, ed., Canadian Environmental Policy: Ecosystems, Politics, and Process (Toronto: Oxford University Press, 1992), 153-58.

10 Kanji uses this measure ("North American Environmentalism").

11 Riley E. Dunlap and Kent D. VanLiere, "The 'New Environmental Paradigm': A Proposed Measuring Instrument and Preliminary Results," Journal of Environmental Education 9 (1978), 10-19.

12 See, for example, Blake et al., "Being Green," 48; Dunlap et al., Health of the Planet; Alan Frizzell and Jon H. Pammett, eds., Shades of Green: Environmental Attitudes in Canada and around the World (Ottawa: Carleton University Press, 1997).

13 Ingelhart, "Public Support."

14 Steven R. Brechin and Willett Kempton, "Global Environmentalism: A Challenge to the Postmaterialism Thesis," Social Science Quarterly 75 (1994), 245-69; Riley E. Dunlap and Angela G. Mertig, "Global Concern for the Environment: Is Affluence a Prerequisite?” Journal of Social Issues 51 (1995), 121-37.

15 Jones and Dunlap, "The Social Bases." 
between humans and the earth. ${ }^{16}$ It is reasonable to expect that these values may cohere with environmentalists' political ideas to shape broader conceptions of the relations among nature/environment and the political world.

\section{Environmentalism and Political Ideas}

Political ideas address how groups of people think, deliberate and make decisions about aspects of life that they share. Political ideas about desired social outcomes (ideologies) conventionally are arrayed on a left/ right continuum. In North American politics, the left has been identified with the use of government to promote a more equal distribution of wealth. ${ }^{17}$ The right is associated with support for an economy based on private enterprise and a government that actively supports it.

The prevalence of environmentalism suggests that it is compatible with varying political ideological perspectives. Indeed, Robert Paehlke, among others, has argued that environmentalism is independent of left/right politics, ${ }^{18}$ that the key questions environmentalism raises centre on the nature and use of technology. ${ }^{19}$ What kinds of technologies to employ? What ecological criteria should guide decision making concerning the use of technology? A person's answers are not necessarily related to that person's opinion on an equal distribution of wealth or an autonomous private enterprise economy. A private enterprise environmentalist may favour the use of taxes and financial incentives to promote environmentally benign technologies; an environmentalist on the left may favour a more direct government role in making such decisions. If Robert Paehlke is correct, we should expect to find these different perspectives within the environmental movement. Environmentalists would tend toward consensus on questions of technology but vary on the role of government, the nature of democracy and the meaning of justice.

Other analysts have linked environmentalism to particular ideologies, arguing that environmental beliefs and values stem from other political commitments. Douglas and Wildavsky have claimed

16 Dunlap et al., Health of the Planet; Kanji, "North American Environmentalism"; Thomas Dunk, "Talking about Trees: Environment and Society in Forest Workers' Culture,' Canadian Review of Sociology and Anthropology 31 (1994), 14-34; and Willett Kempton, James S. Boster and Jennifer A. Hartley, Environmental Values in American Culture (Cambridge: MIT Press, 1995).

17 Robert C. Paehlke characterizes the left/right dimension of politics as a continuum of positions on the role of government in distributing wealth and power (Environmentalism and the Future of Progressive Politics [New Haven: Yale University Press, 1989], 184).

18 Ibid., 177.

19 Ibid., 189. 
radical egalitarianism as the basis of environmentalism. ${ }^{20}$ This is more than an assertion of positive correlation; Wildavsky argues that environmentalists' perceptions of technological risk derive from their distrust of structures of authority and hierarchy in capitalist political economies. ${ }^{21}$ This distrust, in turn, is rooted in an egalitarian political culture that aspires to a "life of purely voluntary association." 22 Egalitarians reject coercion and inequality; they want to build a society in which individuals have equal access to wealth and power. Intriguingly, Wildavsky's conception of egalitarianism reflects both the redistributive priorities of the old left and the democratic imperative of new social movements.

Ellis and Thompson use survey data from the Pacific Northwest of the United States to test Wildavsky's model ${ }^{23}$ their test is limited in that their measure of egalitarianism focuses entirely on the distribution of wealth. By this measure, they find egalitarianism to be strongly related to a new ecological consciousness and to support for environmental spending. Thus those who support environmental goals tend to have a redistributive political agenda. ${ }^{24}$

This result is consistent with those derived by Donald Blake and his colleagues from their surveys of citizens in British Columbia. ${ }^{25}$ Their results also link environmental values, support for environmental policies and green activism, to a left political orientation; they use

20 Mary Douglas and Aaron Wildavsky, Risk and Culture: An Essay on the Selection of Technological and Environmental Dangers (Berkeley: University of California Press, 1982).

21 Ibid., 174-85; and Aaron Wildavsky, "Choosing Preferences by Constructing Institutions: A Cultural Theory of Preference Formation," American Political Science Review 81 (1987), 3-21.

22 Wildavsky, "Choosing Preferences," 7.

23 Ellis and Thompson, "Culture and Environment," 894-95. Their index of egalitarianism includes three items: the world would be a more peaceful place if its wealth were divided more equally among nations; dramatically reduce inequalities between rich and poor, whites and people of colour, men and women; and our country needs a fairness revolution to make the distribution of goods more equal.

24 Ibid., 887-91, 896. They distinguish between egalitarian political culture, as conceived by Wildavsky, and leftist ideology. But their uni-dimensional measure of egalitarianism is easily reduced to a narrow conception of leftist politics. They also test the relation between environmentalist sympathy and ideology. Their indicator of ideology, which is not consistently significant, asks respondents to array themselves on a scale from strongly conservative to strongly liberal. This is a conventional scale in studies of US politics, but note that, reflective of mainstream US politics, there is no left on this scale.

25 Blake et al., "Being Green"; Donald E. Blake, Neil Guppy and Peter Urmetzer, "Environmental Attitudes and Environmental Action: Evidence from British Columbia," this Journal 30 (1997), 451-72. 
an index of neoconservatism to measure ideological orientation. ${ }^{26}$ The strongest association they observe is between political ideology and individuals' willingness to pay for environmental improvements, for example, support for higher environmental taxes and for closing businesses that fail to comply with environmental standards. Neoconservatives are less likely to support such policies than are those who support government programmes to protect the environment. Blake and his colleagues conclude that ideological divisions may constitute an impediment to solving environmental problems, and that the relation between ideology and environmental orientations warrants further study. ${ }^{27}$

Mebs Kanji uses data on Canada and the US from the World Values Survey to further explore this relation. ${ }^{28} \mathrm{He}$ builds on Herbert Kitschelt's work on new social movements in western Europe to measure left-libertarianism, which is characterized by a rejection of centralized state action as the means to solve environmental problems created by industrial society. ${ }^{29}$ Left-libertarians attribute environmental problems to the state-corporate partnership that has governed industrial society. Further, they see this partnership as invasive of personal autonomy. Thus, while environmental protection is a priority for them, they are sceptical of coercive state policy solutions. Instead, individuals and communities are exhorted to live in ways that minimize adverse impacts on the environment. Kanji, following Kitschelt, sees new left-libertarianism as an ideology that has begun to displace the old left agenda of class revolution and redistribution. He notes a significant relation between left-libertarianism and environmental concern. $^{30}$

26 Blake et al., "Environmental Attitudes." Their neoconservatism index uses three items: government should do more to protect the environment, even if it leads to higher taxes; to prevent destruction of natural resources, the government must have the right to control private land use; and protection of the environment requires more extensive regulation of business by government. Affirmative responses to these items result in low neoconservatism scores. Explicit reference to environment or natural resources in each item renders interpretation of the index as a strictly ideological measure problematic.

27 Ibid, 468-70.

28 Kanji, “North American Environmentalism,” 183-204.

29 Herbert Kitschelt, "Left-Libertarian Parties: Explaining Innovation in Competitive Party Systems," World Politics 40 (1988), 194-234; Herbert Kitschelt and Staf Hellemans, Beyond the European Left: Ideology and Political Action in the Belgian Ecology Parties (Durham: Duke University Press, 1990).

30 Kanji, “North American Environmentalism.” His index of left-libertarianism includes five items: left placement on a left-right political scale; low confidence in government; low confidence in civil service; low emphasis on material goods; and desire to live a simple and natural lifestyle. 
A related analysis of environmentalism and new politics identifies the latter with postmaterialism. Ronald Inglehart contends that new social movements promote postmaterial values. ${ }^{31}$ That is, they give priority to political participation and freedom over material welfare and national security. Moreover, postmaterialism becomes more prominent as communities become more affluent. Citizens whose needs for material goods and security are met have the luxury of pursuing postmaterial goals. Inglehart applies this analysis to environmentalism by testing for the relation between support for environmental protection and postmaterial priorities. ${ }^{32}$ Using cross-national survey data, he finds some confirmation of his hypothesis in affluent countries, but in less wealthy countries, he finds no relation between postmaterialism and environmentalism. Others who have used crossnational data have found that material affluence is not a requisite of environmental concern and action. ${ }^{33}$ Citizens of the poorest countries note the poor quality of their environments, express their support for environmental protection and improvement, and engage in forms of behaviour intended to achieve that end. These beliefs and behaviour have no apparent relation to postmaterialism.

Finally, scholars of environmental justice have portrayed environmentalists as elites intent on protecting the material privileges of their class while neglecting the environmental conditions of the less affluent. ${ }^{34}$ Proponents of environmental justice have articulated an environmentalism focused on human health and social justice as well as ecological integrity. ${ }^{35}$ They argue that the mainstream environmental movement neglects these concerns because it lacks a political economic analysis and a commitment to justice. Environmental justice activists and scholars draw on several kinds of evidence to build a blistering critique of mainstream environmental organizations. These include environmentalists' narrow conception of environment,${ }^{36}$ disin-

31 Ronald Inglehart, Culture Shift in Advanced Industrial Society (Princeton: Princeton University Press, 1990).

32 Inglehart, "Public Support," 57-72.

33 See, for examples, Francis O. Adeola, "Cross-National Environmentalism Differentials: Empirical Evidence from Core and Noncore Nations," Society and Natural Resources 11 (1998), 339-64; Brechin and Kempton, "Global Environmentalism"; and Dunlap and Mertig, "Global Concern."

34 See, for example, Laura Pulido, Environmentalism and Economic Justice: Two Chicano Struggles in the Southwest (Tucson: University of Arizona Press, 1996).

35 For example, Luke W. Cole and Sheila R. Foster, From the Ground Up: Environmental Racism and the Rise of the Environmental Justice Movement (New York: New York University Press, 2001).

Ibid., 16, 28-31. 
terest in working with communities of colour $^{37}$ and failure to acknowledge local environmental expertise. ${ }^{38}$

The environmental justice critique of mainstream environmentalism takes us back to Paehlke's argument that environmentalism carries with it no necessary commitments to either the left or right of contemporary North American politics. ${ }^{39}$ Although some environmentalists may embrace the leftist political priority of wealth redistribution, others may support liberal capitalist values and institutions. Still others may focus on non-material (or postmaterial) political goals of democracy and autonomy. None of these theories, nor empirical research, offers a definitive model of the relation between political and environmental ideas. This article further explores this relation by examining the beliefs and values of a sample of $\mathrm{BC}$ environmental activists. The objective is to discern patterns of association between environmental ideas, and beliefs and values related to democracy and social justice. Thus is joined the empirical study of environmental and political belief systems.

\section{Studying the Political Culture of the Environmental Movement}

Political culture refers to those beliefs, values and feelings toward the political system that are widely shared by a political community. Such beliefs shape empirical and affective orientations regarding the goals and conduct of political life, and toward the system's authoritative claims and outputs. ${ }^{40}$ Although most research on political culture focuses on nations, subnational regions, and ethnic communities, researchers have argued that political cultures may be observed from regions to social movements. ${ }^{41}$ Social movements may be defined as sets of actors, linked through informal networks and united by shared

37 Charles Lee, ed., Proceedings: The First National People of Color Environmental Leadership Summit (New York: United Church of Christ, 1992).

38 Devon Peña, "The "Brown" and "Green": Chicanos and Environmental Politics in the Upper Rio Grande," Capitalism Nature Socialism 3 (1992), 79-103.

39 Paehlke, Environmentalism and the Future.

40 Stephen H. Ullman, "Regional Political Culture in Canada: A Theoretical and Conceptual Introduction," in Richard Schultz, Orest M. Kruhlak and John C. Terry, eds., The Canadian Political Process (Toronto: Holt, Rinehart and Winston, 1979), 3-52.

41 David J. Elkins and Richard E. B. Simeon, "A Cause in Search of Its Effect, or What Does Political Culture Explain?" Comparative Politics 11 (1979), 127-45; and Joel Lieske, "Regional Subcultures in the U.S.," Journal of Politics 55 (1993), 888-913. 
beliefs, who challenge an existing social or political order. ${ }^{42}$ It is the shared beliefs that are the focus of our analysis.

Much of the empirical research on political culture is of two kinds. The first uses extended interviews with a small sample of people to identify attributes of the beliefs prevalent in a society. Robert Bellah and his colleagues interviewed people in four communities to explore tensions between individualism and commitments to community in contemporary American life. ${ }^{43}$ The second approach surveys large samples of individuals to identify patterns of beliefs and values that are statistically generalizable. ${ }^{44}$ The first type of study facilitates intensive examination of the subjects' understandings of politics, but the interviewers' interpretations are unconstrained by measurement rules, and research designs are culturally static and seldom permit replication. The second type imposes the investigator's conceptions of politics by using predefined categories in the survey. Further, responses to close-ended questions may not convey subjects' understanding of response categories.

\section{$Q$ Methodology}

The research on which this article is based addresses the limitations noted above by using Q methodology. Political scientists increasingly have used $\mathrm{Q}$ methodology to examine individuals' subjective understandings of their political worlds. ${ }^{45} \mathrm{Q}$ provides an alternative to the more conventional R-methodological approaches which attempt to

42 Mario Diani, "The Concept of Social Movement," The Sociological Review 40 (1992), 1-25; Manfred Kuechler and Russell J. Dalton, "New Social Movements and the Political Order: Inducing Change for Long-term Stability?" in Russell J. Dalton and Manfred Kuechler, eds., Challenging the Political Order: New Social and Political Movements in Western Democracies (New York: Oxford University Press, 1990), 277-300.

43 Robert Bellah, Richard Madsen, William M. Sullivan, Ann Swidler and Steven M. Tipton, Habits of the Heart: Individualism and Commitment in American Life (Berkeley: University of California Press, 1985).

44 See, for example, Allan Kornberg and Harold D. Clarke, Citizens and Community: Political Support in a Representative Democracy (Cambridge: Cambridge University Press, 1992).

45 See, for example, John S. Dryzek and Jeffrey Berejikian, "Reconstructive Democratic Theory," American Political Science Review 87 (1993), 48-60; John S. Dryzek and Valerie Braithwaite, "On the Prospects for Democratic Deliberation: Values Analysis Applied to Australian Politics,' Political Psychology 21 (2000), 241-66; and Dan B. Thomas and Larry R. Bass, "The Postelection Campaign: Competing Constructions of the Clinton Victory in 1992,' Journal of Politics 58 (1996), 309-31. Some Q-studies of environmental values include: John Barry and John Proops, "Seeking Sustainability Discourses with Q Methodology," Ecological Economics 28 (1999), 337-45; and N. Patrick Peritore, "Environmental Attitudes of Indian Elites: Challenging Western Postmodernist Models," Asian Survey 33 (1993), 804-18. 
characterize an objective set of political facts. ${ }^{46} \mathrm{Q}$ is further distinguished from $\mathrm{R}$ methods in its focus on description and classification of subjects rather than on correlation of variables. Most Q studies employ factor analysis to classify subjects according to their rankings of a sample of statements about the domain under study.

Data collection in Q studies comprises two stages. The first stage generally involves semistructured interviews with participants in the relevant domain which are used to construct a sample of relevant statements (the Q-sample). The population from which this sample is derived is termed the concourse. The ideal concourse in our study would be the set of all statements that BC environmental activists might make about the environment and politics. Statements drawn from interviews constitute the sampling frame (a best approximation of the population). Q-samples are drawn from this frame to reflect the kinds of claims made by participants in the domain, typically by dividing the concourse into categories and selecting statements representative of each category. The representativeness of Q-samples will reflect the familiarity of the investigator with the concourse, the skill of the investigator in engaging subjects in relevant discussion, and the selection of individuals for initial interviewing.

During the second stage, a sample of respondents (P-sample) is asked to sort the statements according to their level of agreement with each. Because Q methodology does not require the use of sample statistics to estimate population parameters, a probability sample is not necessary. The objective in Q methodology is to discover all of the perspectives on a topic within the population. ${ }^{47}$ Thus the ideal P-sample will include a sufficient variety of individuals such that all perspectives are included within the sample. Typically, a purposive sample is constructed to capture demographic variation within a population.

Sorters are asked to rank the statements in a quasi-normal distribution to ensure variation in responses and to facilitate sorters' reflection on their priorities. ${ }^{48}$ The sorting procedure is designed to elicit the

46 Several authors outline key attributes of the approach: Steven R. Brown, Political Subjectivity: Applications of Q-Methodology in Political Science (New Haven: Yale University Press, 1980); "Q Technique and Method: Principles and Procedures," in William D. Berry and Michael S. Lewis-Beck, eds., New Tools for Social Scientists: Advances and Applications in Research Methods (Beverly Hills: Sage, 1986), 57-76; and Bruce McKeown and Dan Thomas, Q Methodology (Newbury Park: Sage, 1988). The following discussion of Q derives primarily from these sources..

47 This is different from the objective of $\mathrm{R}$ studies, which is to make probabilistic statements about the likelihood of encountering particular types of individuals or relations in a population.

48 Critics of Q methodology have challenged the use of a forced distribution for sorting. McKeown and Thomas have addressed this issue ( $Q$ Methodology, 35). To 
structure of respondents' priorities, resulting in an array of items comprising a Q-sort for each individual. A group of sorts can then be assessed to reveal if, and in what ways, the respondents see a topic similarly. ${ }^{49}$ Factor analysis is then used to map the pattern of variation in priority attached to each statement. This pattern may suggest clusters or groupings of subjects, each reflecting a particular view on the topic of study.

The use of Q-methods to describe and classify the beliefs of environmental activists may provide insights about the environmental movement not obtained through more conventional survey research. They can generate more accurate descriptions of political cultures, revealing subtleties while achieving replicability. The data may indicate new dimensions of political culture and yield better measures of its various elements, ${ }^{50}$ which can then be used to construct mass surveys and to test hypotheses about the relations among demographic and structural variables and the political culture of the environmental movement in North America.

\section{The Q-Sample and the Sorting Process}

This analysis focused on beliefs and values associated with the intersection of environment and democratic politics. ${ }^{51}$ The interview questions probed beliefs about the nature of power, politics and government, as well as about the functioning of environmental systems. Further, values were elicited about how political decisions should be made and the criteria that should guide environmental decision making in particular.

The Q-sample for this study was derived from the transcripts of 43 semistructured interviews with environmental activists in BC. A schedule of 12 substantive questions guided the interviews, which lasted from one to three hours. ${ }^{52}$ Review of the transcripts generated a

avoid getting lost in a lengthy discussion here, we note only that respondents who were unable to conform to the distribution were allowed to deviate. Further, no response structure or scale is without tradeoffs. By presenting respondents with a distribution, we attempted to push them to examine their priorities (while not insisting that they make up priorities) and to minimize the effects of individual preferences for particular places on a scale (tendencies to be agreeable or disagreeable).

49 Brown, "Q Technique," 59-60.

50 See, for example, Dryzek and Berejikian, "Reconstructive Democratic Theory," 48-60.

51 Public opinion researchers commonly distinguish between beliefs that are empirical and values that are normative. Values reflect moral guidelines or principles; they indicate commitments to what is right or just. In contrast, beliefs are assertions of fact. See Kempton et al., Environmental Values, 12, 87-88.

52 These interviews were conducted between September 1996 and December 1997. For a list of questions and discussion of the results of the semistructured inter- 
concourse of 500 statements. These statements were grouped into six categories: policy making and institutions; democracy and citizenship; fairness and social justice; community; environment, nature, and humans; and environmentalism and the environmental movement. Representative statements for each category were selected to create a sample of 54 statements (Appendix), with fairly equal numbers in most categories. ${ }^{53}$ Statements were selected to represent the range of views expressed within each category as well as the range of environmental issues discussed by the activists. The statements were numbered randomly and printed on cards, which were shuffled and presented to each activist for sorting.

The Q-sorts were conducted between January and June of 1998. Sorters were asked to rank statements along a gradient of similarity to their views-from +5 (most like my view) to -5 (most unlike my view) - in a quasi-normal distribution. After the sort was completed, sorters were asked to comment on any statements they found confusing or ambiguous. Further, they were queried regarding the statements they ranked at the extremes as well as any statements they found particularly interesting.

\section{The P-Sample}

The P-sample was designed to ensure that we accessed the range of environmental/political ideas within the $\mathrm{BC}$ movement. Thus activists from different regions, working on various types of environmental issues, with varying levels of involvement and visibility and with varying demographic attributes were included. Directories and newsletters of environmental organizations were consulted, and interviews held with key informants to identify potential interviewees. Also, each person interviewed was asked to suggest other interviewees. The P-sample includes 46 individuals involved in a range of environmental issues and from several regions of $\mathrm{BC}$ (Table 1).

The sample varied by sex, ethnicity, age, education, occupation and income. ${ }^{54}$ Members of the P-sample ranged in age from 22 to 77. Most were women; most had graduated from college; and fewer than half were employed by environmental organizations. Conventional

views, see Debra J. Salazar and Donald K. Alper, "Beyond the Politics of Left and Right: Beliefs and Values of Environmental Activists in British Columbia," BC Studies 121 (1999), 5-34.

53 The exceptions were the policy making/institutions category with 19 statements and community with 4 statements. Some statements fit into more than one category.

54 The p-sample is not intended to be representative in a statistical sense, only to reflect the range of kinds of people and involvement in the $\mathrm{BC}$ environmental movement. 


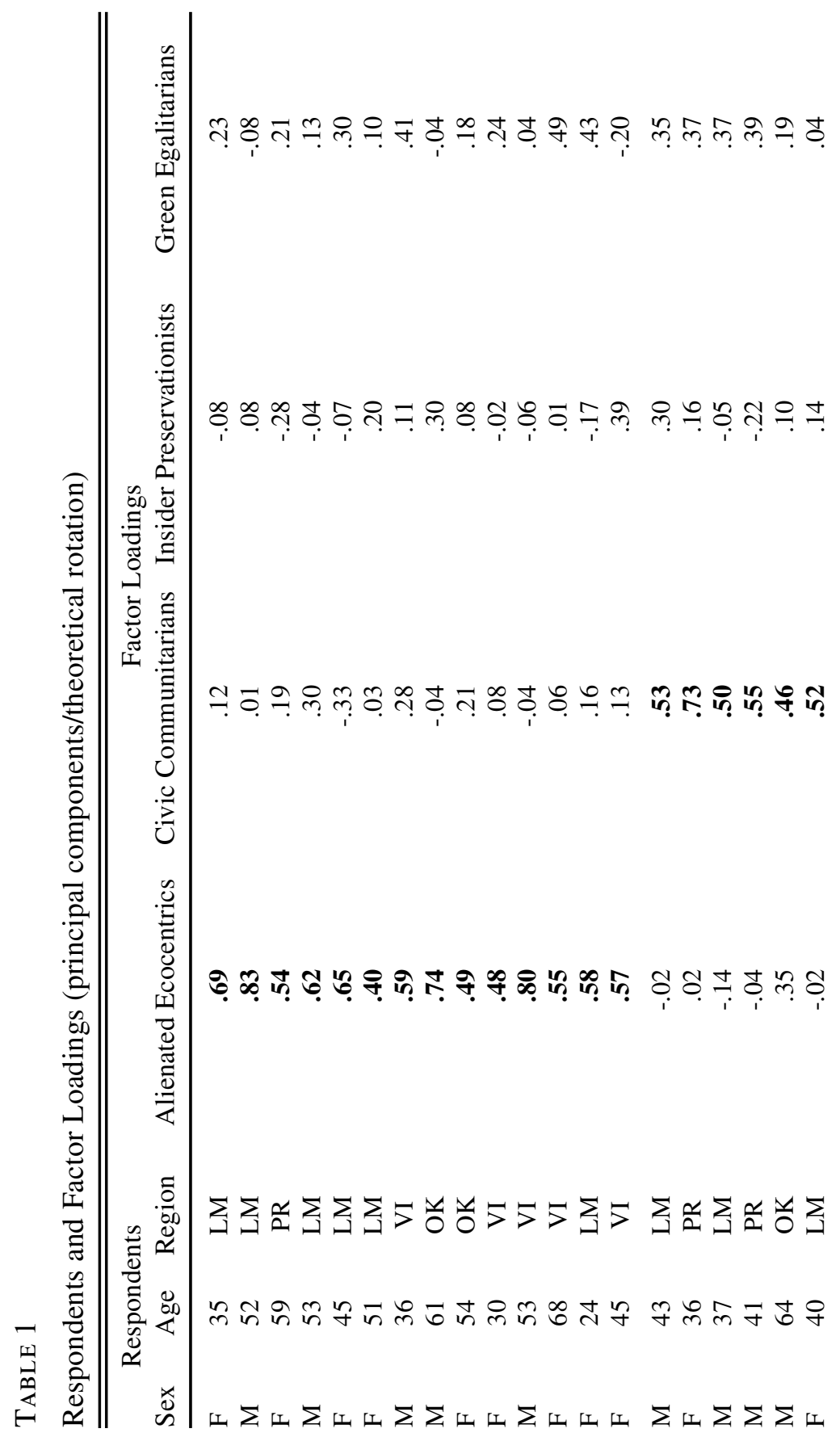


남

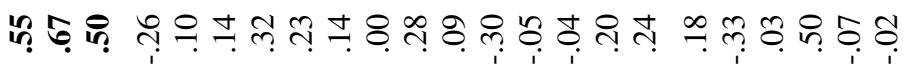

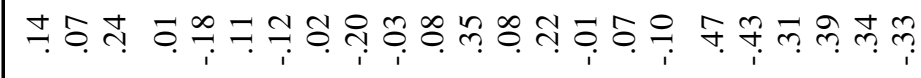

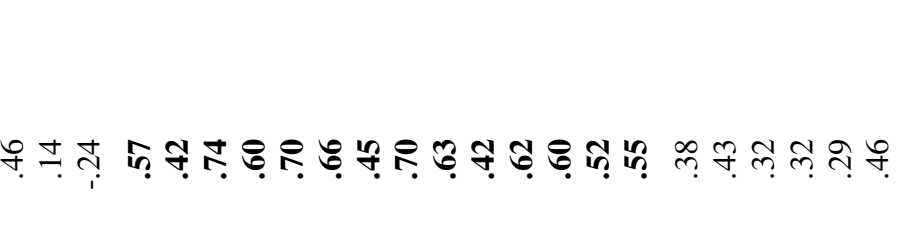




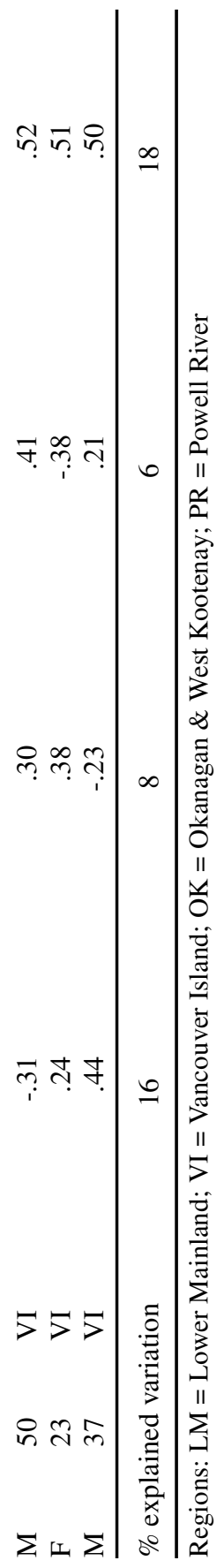


religion tended not to be an important part of their lives, though several were church members who attend regularly and others emphasized their commitment to non-traditional forms of spirituality. ${ }^{55}$ Four were Chinese-Canadian; four were members of Aboriginal communities; thirty-eight were white; several identified as mixed racial/ethnic. Sixteen were born outside Canada, the United Kingdom being the most common country of origin.

\section{Four Perspectives on Democracy, Social Justice and Environment}

The meaning and performance of democratic systems are among the central priorities of the activists who participated in the study. Perspectives on democracy vary within the sample, as do views of social justice, nature and the role of the environmental movement. As might be expected, a key dimension of variation among the activists is the relative moral status accorded humans and other creatures. Nearly coincident with this dimension is the priority attached to environment/nature relative to other public concerns (for example, social justice). A second axis along which the sorts may be discriminated is the confidence expressed in Canadian political economic institutions. A final observation is that there was not consensus among activists on issues of social justice. ${ }^{56}$ Indeed they varied considerably in the extent to which they considered these issues salient as well as in their understanding of justice. Moreover, activists' statements about social justice ranged beyond concern for the distribution of wealth to include the rights of excluded groups (indigenous peoples), the relation between poverty and environmental destruction and the fairness of decision-making processes.

Using principal components factor analysis, four groups of activists are identified, each defining a perspective on environment and politics. ${ }^{57}$ The first perspective is termed alienated ecocentrism; the

55 A study in the US found a conservative Christian theological commitment to be negatively related to support for environmental protection (James L. Guth, John C. Green, Lyman A. Kellstedt and Corwin E. Smidt, "Faith and the Environment: Religious Beliefs and Attitudes on Environmental Policy," American Journal of Political Science 39 [1995], 364-82). Consistent with this finding, none of the activists indicated membership in a conservative denomination. The sample included six members of Christian denominations including three Roman Catholics, one Mennonite, one Unitarian and one member of the United Church of Canada. Two of the Aboriginal interviewees participate in the traditional spiritual practices of their nation. Five of the activists identified as Buddhists, several others as pagans or pantheists.

56 Statements 7, 8, 12, 17 24, 33, 38, 43 and 44 address issues of social justice. None of these statements generated consensus among the activists.

57 The theoretical rotation option of the programme, PQMethod (available at http://www.rz.unibw-muenchende/ $/ \mathrm{p} 41 \mathrm{bsmk} / \mathrm{qmethod}$ ) was used to analyze the 
second, civic communitarianism; the third, insider preservationism and the fourth, green egalitarianism (Table 1). Each perspective (factor) is described below by examining the factor scores for statements that define its key aspects. ${ }^{58}$ Review of the factor scores suggested four themes that differentiated the perspectives: humans and nature, institutions, tactics and social justice. Our analysis of each perspective centres on the highest- and lowest-ranked statements related to each theme. Interpretations of the perspectives derive from the factor scores and from post-sort interviews. ${ }^{59}$ The demographic attributes of the people associated with the factors are examined in order to identify any patterns that might generate hypotheses.

\section{Alienated Ecocentrism}

Fourteen activists' sorts loaded significantly on the first factor. These sorts are distinguished by their embrace of ecocentrism, the priority they attach to environmental concerns and their alienation from Canadian political economic institutions (Table 2). Their ecocentric orientation is indicated by the fact this was the only factor with a positive evaluation of the claims that humans are no better than other creatures, and that the world would be better off without us (13). Further, this factor has the highest score for statement 20 with its assertion of an absolute priority for environmental concerns. The strong rejection of the claim that God created the world and gave humans oversight responsibility (1) reflects a perception of human arrogance communicated by the claim that humans have the responsibility to "look after" the world. As one activist noted, "we have responsibility to treat the earth properly, not to look after it."

Alienated ecocentrics also strongly reject political economic institutions, including corporations $(3,16)$, political parties $(42)$ and politicians (45), all of which are seen as undemocratic, corrupt and destructive. Moreover, they consider institutional failures to be exacerbated by trade liberalization. One interviewee's comment was typical: The Multilateral Agreement on Investment "is really scary. Government leaders are traitors. What are they getting out of these agreements?"60

sorts. The rotated factor solution yielded 37 of the 46 sorters with significant $(\mathrm{p}<.01)$ loadings on one of the four factors. Of those sorts that were not significantly associated with one of the factors, all load highly on two or more. Thus these individuals held beliefs and values associated with more than one perspective.

58 See the Appendix for a complete list of statements along with weighted factor scores for each.

59 Unless otherwise noted, quotations are taken from the post-sort interviews.

60 Sorts were conducted just before the Multilateral Agreement on Investment (MAI) was scheduled for adoption; it was the subject of an impressive counter- 


\section{TABLE 2}

Defining Statements for Alienated Ecocentrics

(statements are edited for brevity; see Appendix for complete text)

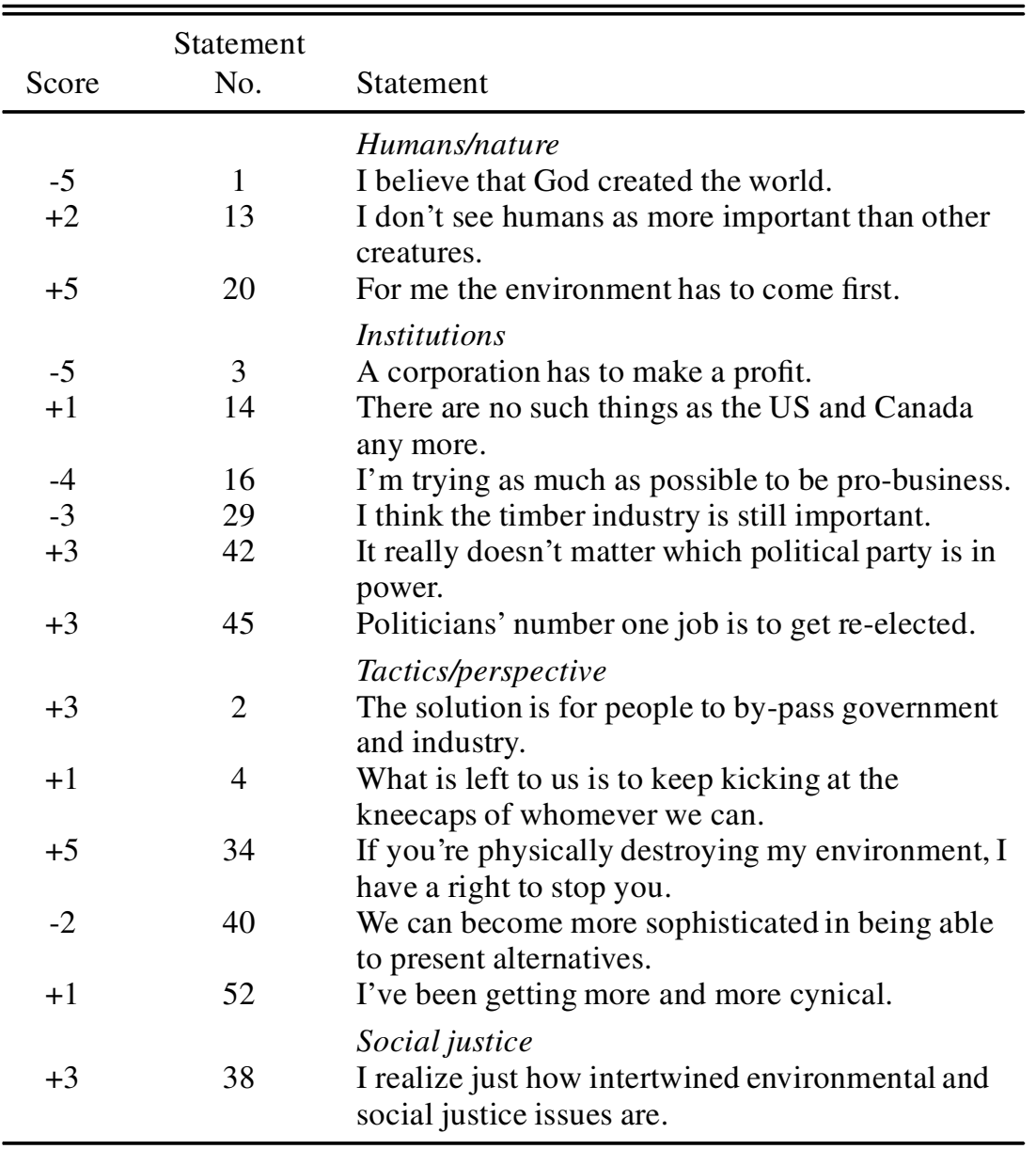

This perspective on institutions is reflected in the activists' tactical preferences. They strongly endorse direct action, both physical confrontation (34) and consumer choice (2). Their pessimism about the potential for responsive government is suggested by their scores for statements 4, 40, 45 and 52. In reference to a claim that facts were an important political resource (26), one activist offered this observa-

mobilization across Canada. The effects of this campaign were reflected in the frequency of participants' comments on the MAI and the gravity with which they viewed it. 
tion about politicians and bureaucrats: "The level they understand is rotten tomatoes and civil disobedience. The facts don't usually make any difference."

Alienated ecocentrics did not articulate a fully-formed ideology; their rejection of existing institutions was not accompanied by any consensus on the kind of social organization that would promote environmental protection and democratic decision making. They were ambivalent regarding the appropriate scale of governance (5) and they differed among themselves on the nature of democratic citizenship $(6,10,26,47)$. Indeed, statements about politics (processes of collective decision making) are not among the most salient for this group. Rather, the most negative and most positive scores are for statements about the importance of environment/nature and for expressions of disgust for corporations. Nor are issues of social justice central to this discourse. While alienated ecocentrics acknowledged a relation between poverty and environmental exploitation (38), they were ambivalent about the extent to which distribution of parks in the city (8) should be of concern to environmentalists and about the role of First Nations in environmental decision making $(17,43)$.

\section{Civic Communitarianism}

All six activists who loaded highly on this factor work on wetlands/ wildlife habitat issues. Moreover, three of the six are Aboriginal people who live on reserves and are active in reserve governance.$^{61}$ Civic communitarians tend to live in rural or suburban areas and focus their activism on municipal governments (Table 3). They express optimism about the capacity of Canadian institutions to address environmental problems $(4,14,37,51,52)$. Their civic-mindedness is reflected in their commitment to grass-roots and local processes. They tend to be conciliatory, and are willing to accept and work with political opponents (especially fellow members of their communities); they recoil at statements that insult others (37). Expressing a common sentiment, one activist declared: "I am not disgusted with the IWA [International Woodworkers of America]. They are just people who are doing the best they can."

Civic communitarians also tended to oppose disruptive tactics $(21,34)$. A typical comment about such tactics was: "Confrontation may be necessary once in a blue moon but it won't solve long-run problems." In response to the call for kneecap kicking (4), one respondent noted that one would likely "get sore toes or a punch in the nose-people are

61 Their presence is reflected in the scores on statements related to First Nations' right to participate in environmental decision making (43) and in sensitivity to negative characterizations of First Nations' governments $(17,31)$. 
TABLE 3

Defining Statement for Civic Communitarians

(statements are edited for brevity; see Appendix for complete text)

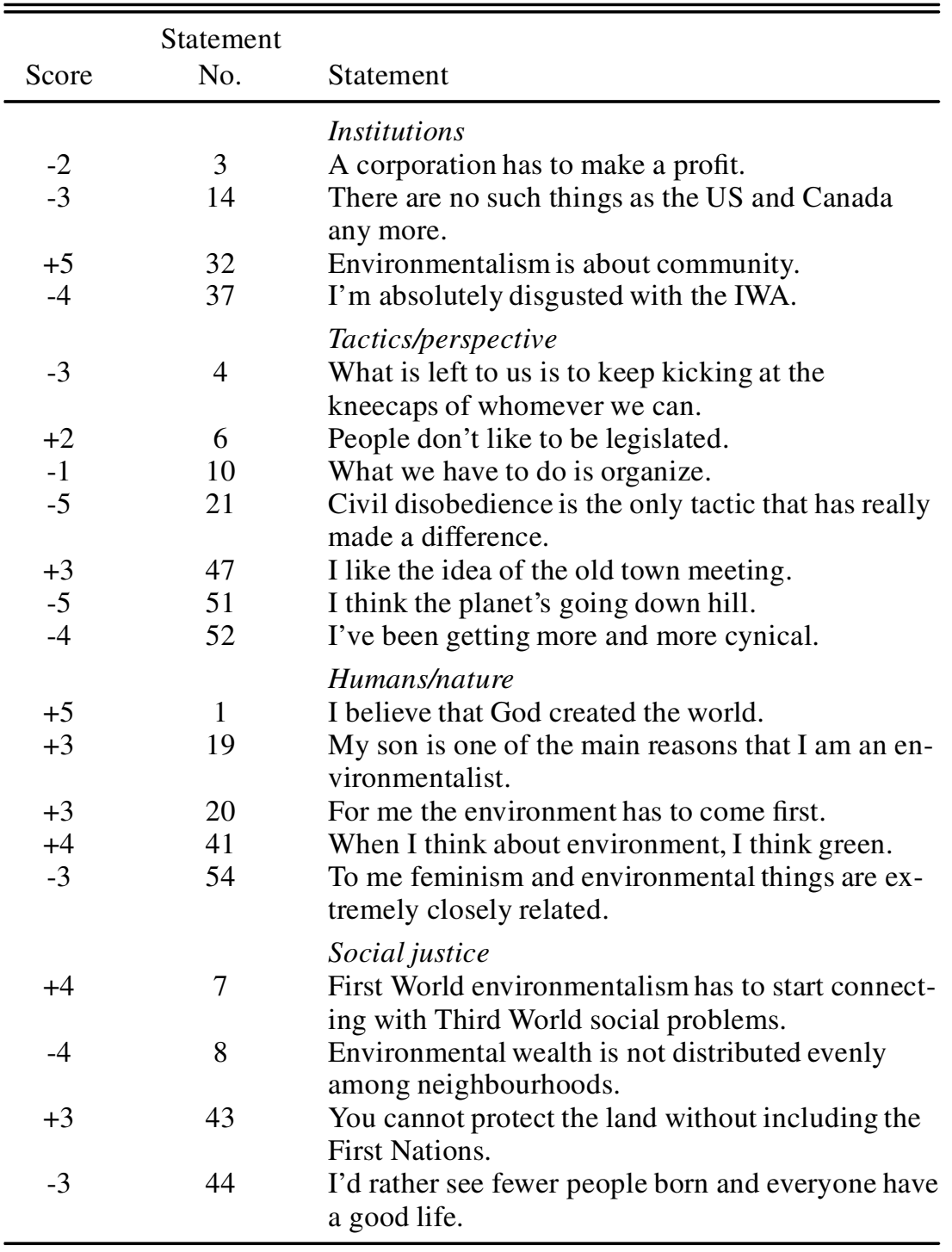

going to learn to hate environmentalists." Rather than confrontation, civic communitarians emphasized co-operative interaction with fellow citizens on a human level: "This should be about educating people on a heart level so they will want to change" (6). Similarly, they believe that adopting a "battle mode" would not enlist the support of politicians; instead, "you have to touch a piece of their humanity." 
Spirituality (1), family (19) and community $(32,47)$ are central to their environmentalism. Though civic communitarians are among the most conventionally religious activists in the sample, several conceive of God broadly as spirit and see a spiritual connection that links all of creation (including corporate executives). This connection unites people in families and communities, and strengthening these institutions, rather than criticizing or tearing down other institutions, is the focus of their political activity. Thus civic communitarians articulate a politics of grass-roots activism (47) and believe that an active and communityspirited citizenry can rescue Canadian political institutions from corporate dominance $(14,52)$.

While civic communitarians recognize a connection between social injustice and resource exploitation $(7,38)$, their focus is on wild environments (41) rather than on cities (8). Moreover, they tend to place high priority on the environment (20) relative to other public issues. Social justice issues usually do not have high salience for them.

\section{Insider Preservationism}

Insider preservationists are distinguished by their support of private enterprise, their pragmatic posture toward Canadian political institutions and their focus on wilderness policy (Table 4). Two lawyers and one technical worker in the private sector comprise this group; all are men. The lawyers are employed by major environmental organizations, with relatively well-staffed offices in Vancouver. Insider preservationists' perspective on environmental politics may reflect their access to conventional political economic channels and the ease with which they interact with officials in both governmental and business sectors. The central political location of the two lawyers suggests the importance of this perspective.

The extent of insider preservationist support for private enterprise is unique among the activists. They see business (and corporations in particular) as essential to a well-functioning society $(3,16)$. One of the lawyers noted that "the corporate form is a way of organizing society that works in a lot of ways. We need some legal entity that is distinct from the individuals who work for it." Their support for private property (22) is especially notable among the four perspectives. Further, they were the only group positively disposed toward the timber industry (29) and negatively inclined toward the IWA (37).

Insider preservationism is further defined by a pragmatic posture toward politics and, especially, Canadian political institutions. This is shown in one activist's reaction to other environmentalists' fears about globalization: "Globalization is a reality, driven by consumerism and population pressures. It is a threat but nation-states will retain sufficient sovereignty." Insider preservationists reject negative characterizations of the party system (42) and of government bureaucrats (39). 


\section{TABLE 4}

Defining Statements for Insider Preservationists

(statements are edited for brevity; see Appendix for complete text)

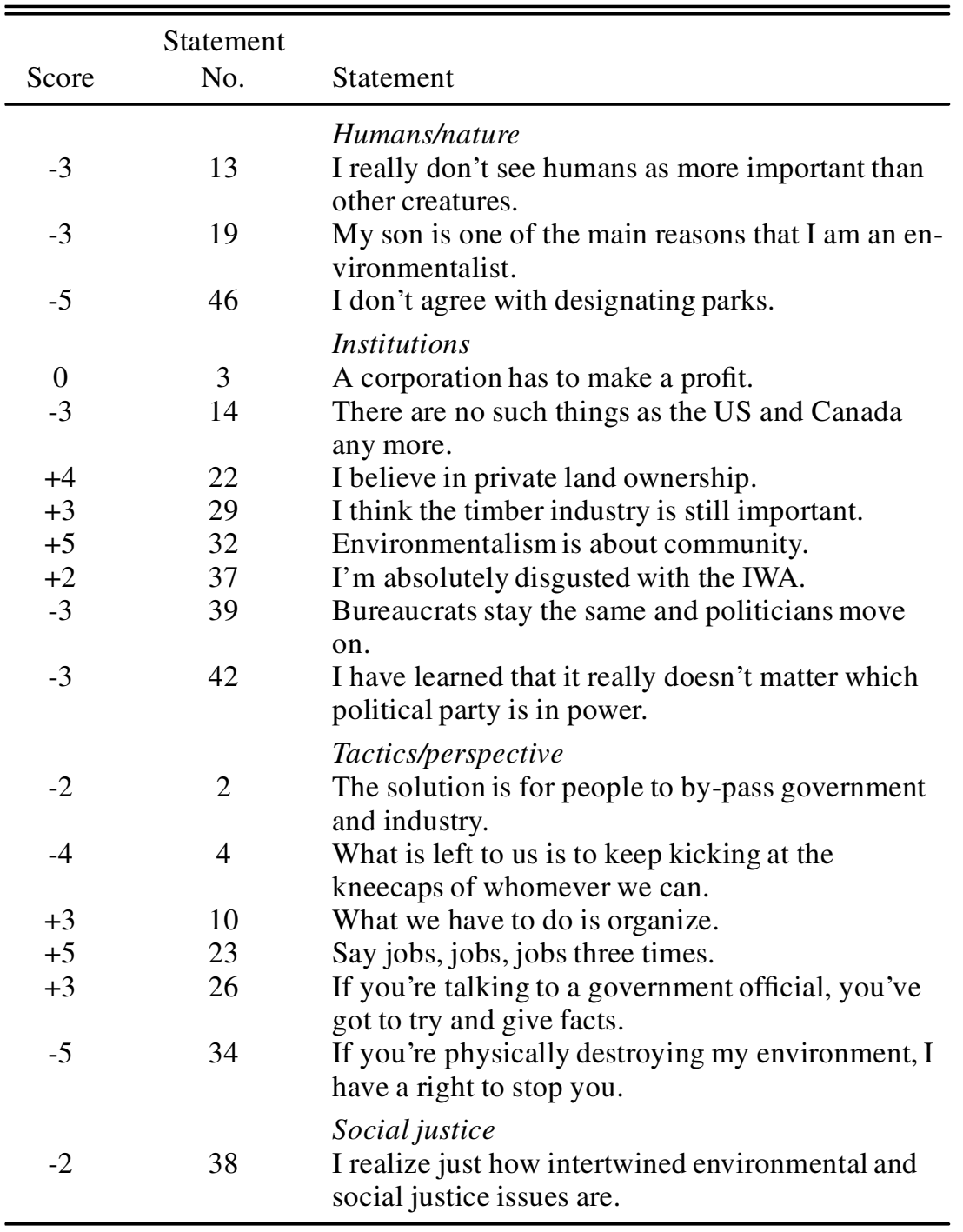

They believe that reasoned and factual analyses will influence public officials (26). Their lukewarm disposition toward participatory democracy $(47,49)$ suggests an elitist distrust of the masses and confidence in experts. Insider preservationists tend to embrace moderation as a political strategy $(10,40)$ and reject disruptive tactics $(24,34)$. One of the lawyer's persistent emphasis on the need for environmentalists to offer 
an economic programme provides additional evidence of pragmatism: "We have to address economics because the public is looking for jobs, moral purity notwithstanding."

This emphasis on economics was not accompanied by an assertion of economic egalitarianism; social justice issues tended not to be salient for insider preservationists. Moreover, they tended to distinguish between environmental and social justice problems; they did not see them as necessarily linked. Their reactions to statement 38 about the relation between social injustice and environmental exploitation are illustrative: "These issues are intertwined, but environmentalists can become ineffective if they think too much about social justice." A similar response was: "This is true on a global scale, but not all environmental issues are social justice issues. It may not be effective to try to move them together."

The third defining element of insider preservationism is the priority attached to wilderness protection, coupled with a tendency to ecocentrism. Creation of parks and reserves is their key priority (46). Though insider preservationists rejected the strong ecocentric statement (13), their scores were based on pragmatic reasoning about the political usefulness of the statement's call for leaving the world "to the sea lions." The ecocentrism at the core of their activism was revealed by one's final reflective comment: "At the end of the day, what I am motivated by is protecting the environment for its own sake, not human economic benefits or health benefits."

\section{Green Egalitarianism}

For green egalitarians, social justice is a key political priority and is inextricably linked to environmental problems and their solution (Table 5). Green egalitarianism is further defined by its broad conception of the environment, support for participatory democracy and critique of a political economy controlled by private actors with little accountability to truly democratic institutions. Those activists whose sorts loaded most strongly on this perspective are evenly divided between men and women, are employed in a variety of settings, are not concentrated in any single region and are broadly distributed by age.

Green egalitarians' commitment to social justice is revealed in the priority they give to the need for environmentalists in wealthy countries to address poverty and environmental destruction in poor countries (7). They were most emphatic about seeing poverty as a source of environmental exploitation (38) and about including Aboriginal people in natural resource decision making (43). Their perspective on these issues reflects a commitment to redistribution of wealth and power in the context of environmental politics. This commitment also is revealed in their response to the claim that the geographic distribution of parks in Vancouver reflects the distribution of wealth in the city 


\section{TABLE 5}

Defining Statements for Green Egalitarians

(statements are edited for brevity; see Appendix for complete text)

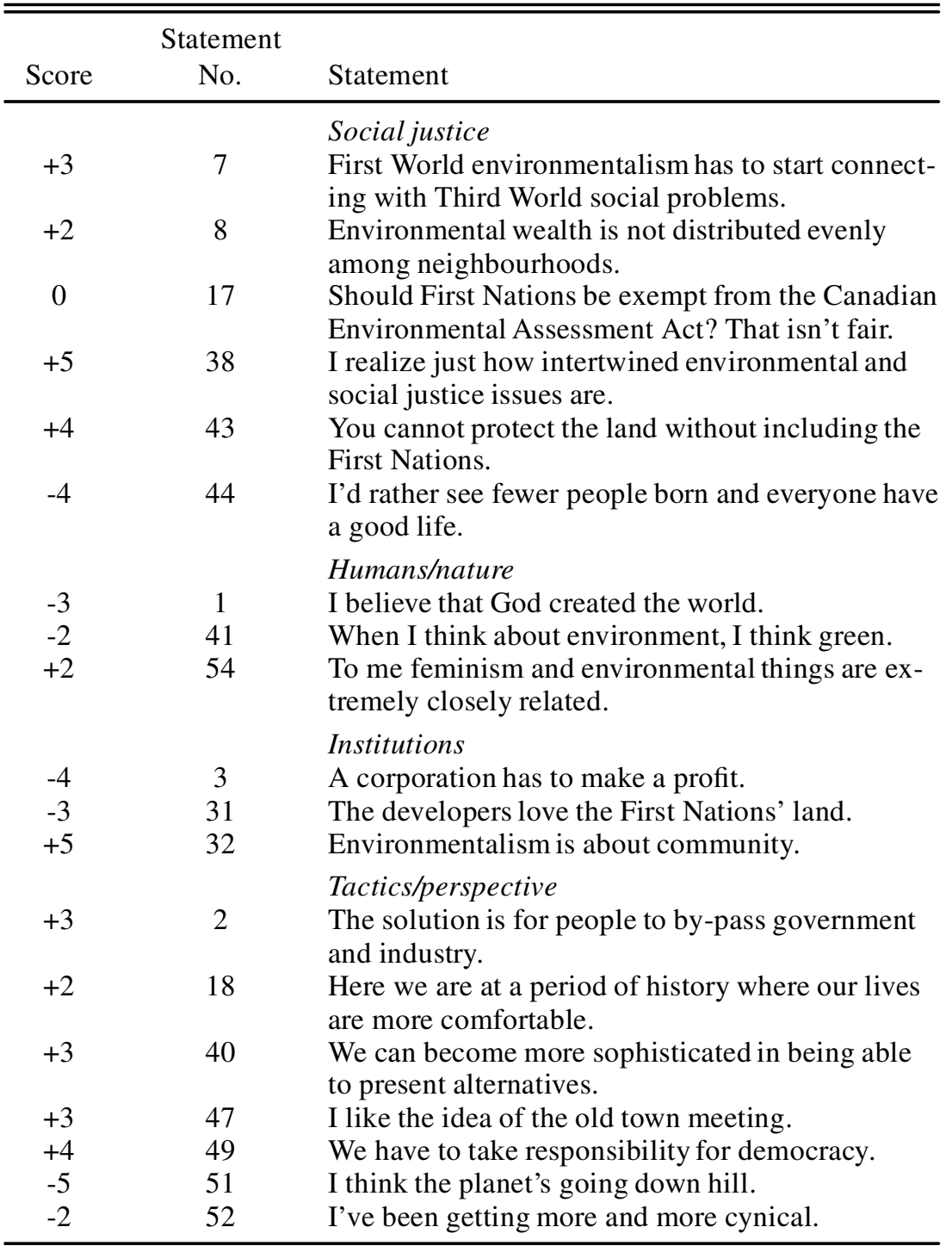

(8); they were the only group with a positive score on this statement. This score was consistent with their unwillingness to conceive of the environment as something apart from humans (41); they are, perhaps, more concerned than any other activists with urban environments.

These activists also strongly criticize their province's political institutions and believe that more participatory institutions would 
strengthen democratic governance $(47,49)$. Though green egalitarians offer the most radical political economic critique, they voice a firm belief that the prospects for change are good $(4,40)$. As one noted: "I still have some hope for the voting system. It's just because of apathy that it's not working; it just needs to be used." Their conception of political participation includes nongovernmental channels (2). But their belief in the efficacy of these channels is not exclusive: "It's important to do things as individuals (shop locally, drive less ... ) but I don't think the solution is to by-pass government and industry. It's our responsibility to keep them on track."

Green egalitarians are the most critical of capitalist structures. They see corporations (synonymous with multinational forest companies for most of the activists we interviewed) as extremely problematic (3), though they do not offer a single approach to challenging corporate power. One activist argued for seeking social change through electoral politics: "Corporations have a lot more influence than the general public. But that doesn't make me want to tear up my ballot. It makes me want to speak out more and use my ballot responsibly." Another suggested that consumer purchasing behaviour could be exploited: "Let the people in boardrooms do what they will. It doesn't matter if people don't buy their products."

Finally, the green egalitarian perspective was the only one with a consistently feminist analysis of the environment. Green egalitarians were the only group to see positively the assertion of a relation between environmental destruction and the oppression of women (54). Moreover, their response to the statement on population (44) asserted the primacy of reproductive rights. One activist's comment was typical: "Yes, I'd rather see fewer people born. But I also believe people have a right to have children." A similar response characterized the statement as a "dangerous thing to say. It reeks of population control, control of reproductive rights, immigration. There are a lot of reasons why people in developing countries have a lot of children; it is complicated." 62

\section{Consensus Issues: The Balance of Nature and the Imbalance of}

\section{Political Economy}

While questions of moral value (humans and nature) and political strategy revealed key differences among the four perspectives, there was consensus on two empirical issues, one ecological, the other polit-

62 Responses to this statement also focused on the need to address poverty independently of population. These quotations are typical: "A smaller number of people will not necessarily improve quality of life; that is a distribution of wealth/political problem" and "No matter how many people there are, there will be class differentiation. Fewer people will not erase poverty." 
ical economic (Table 6). The two most prominent points of agreement are empirical claims about the nature of ecosystems (11) and about the political economy of forests (53). The activists hold a view of ecology as a carefully balanced web, or "chain," in which disruption of one link could destroy the entire system. This view is strongly and uniformly held across the groups. They view forest companies as powerful "outside" entities that have been allowed to steal provincial resources. Only the insider preservationists show some dissent from this view.

\section{TABLE 6}

\section{Consensus Statements}

(statements are edited for brevity; see Appendix for complete text)

\begin{tabular}{cl}
\hline $\begin{array}{c}\text { Statement } \\
\text { No. }\end{array}$ & $\begin{array}{l}\text { Statement/Scores for each factor } \\
\text { (Ecocentrics, Communitarians, Preservationists, Egalitarians) }\end{array}$ \\
\hline 11 & $\begin{array}{l}\text { When you cut the forests down you wreck the streams, you } \\
\text { lose the fish. } \\
\end{array}$ \\
& $+4 \quad+4 \quad+4$ \\
53 & $\begin{array}{l}\text { The way it's structured right now you have this cut and run } \\
\text { mentality. } \\
+4 \quad+2+3 \quad+3\end{array}$ \\
5 & $\begin{array}{l}\text { I don't see Canada as a viable entity ... I'm a big fan of ... } \\
\text { bringing things down to the local level. } \\
\\
-3 \quad-3 \quad-4 \quad-1\end{array}$ \\
\hline
\end{tabular}

The third consensus statement (5) addresses Canadian identity. It challenges the "viability" of Canada and asserts a preference for local or regional governance structures. Activists who ranked this statement negatively tended to support the latter assertion but to reject the former. Most argued that Canada is not only viable but laudable. Though acknowledging imperfections, many of the activists argued that the Canadian people, relative to other countries, have created a society that is decent and just. The following quotations reflect some of the range of characterizations of Canada and Canadian-ness: "There are so many identities; there is a high degree of tolerance and a willingness to co-operate and find solutions;" "I am a small n, nationalist;" and "All those times I sang the national anthem as a kid and having a national radio station must have done something. I don't like to admit it, but being Canadian is important to me." Other activists cited the social safety net, a Canadian commitment to care for fellow citizens and Canadian humility (contrasted with American arrogance). Canadian identity was important for most of the activists. 


\section{The Activists' Political Ideas}

Some analysts associate environmentalism with left ideology. Are BC environmental activists leftists? The results are mixed: green egalitarianism fits most definitions of left politics; civic communitarianism and alienated ecocentrism share some priorities with the left, especially opposition to corporate hegemony; but even with the broadest definition of left politics, it would be difficult to classify insider preservationism as leftist.

The green egalitarian perspective most closely resembles the egalitarianism that Wildavsky finds at the root of environmentalism. ${ }^{63}$ Redistribution of wealth and power is one of their central concerns. Moreover, they see radical reform of the political economy as a necessary condition for environmental protection. But Blake's measure of left orientation, as support of an expanded role for government, does not capture the ethos of green egalitarianism. ${ }^{64}$ Though green egalitarians are not prepared to dispense with government, they were deeply sceptical of the BC government at the time of the study. Further, they had little confidence that any of the major political parties had the will or the capacity to transform government adequately. Thus while green egalitarians supported a stronger Forest Practices Code and more stringent regulation of pulp mills, their assessment of $\mathrm{BC}$ political economic institutions suggests that such policies are unlikely to be adopted. The premise underlying their activism is that mobilization of citizens will force government and corporate policy makers to bend to the will of the people. Their support for grass-roots democracy $(47,49)$ and emphasis on community (32) suggests a model of politics in which power is amassed in the extra-governmental arenas of civil society, then used to shape social change. Green egalitarianism clearly constitutes the left wing of $\mathrm{BC}$ environmental activism, but this left cannot be reduced to preferences for wealth redistribution or a government with an extensive regulatory structure. Fundamental beliefs about the locus of democratic political power (in civil society) and the (essential) connection between protecting the earth and creating just societies shape their tactical and policy preferences.

Redistribution was not central to alienated ecocentrism, civic communitarianism or insider preservationism. Activists associated with these perspectives recognized some relation between poverty and environmental destruction. They differed in their view of the scope of that relation (poverty may not be a source of all environmental problems) and the wisdom of linking an environmentalist political agenda with the redistribution of wealth. Insider preservationists were most

63 Wildavsky, "Choosing Preferences," 7.

64 Blake, et al., "Environmental Attitudes." 
overtly opposed to such a linkage. Civic communitarians and alienated ecocentrics tended not to oppose it explicitly, but neither did they argue that addressing poverty is necessary for preventing environmental destruction.

\section{Social Justice as Fair Procedures}

The meaning of justice around which the activists converged focused on the fairness of democratic procedures. ${ }^{65}$ In this conception, a political decision is fair or just if all citizens have an opportunity to voice their concerns in the decision-making process and if that process takes those concerns seriously and treats them equally. A decision-making procedure that excludes some citizens or weights the concerns of others because of their wealth is not democratic and does not result in justice. ${ }^{66}$

The most glaring example of injustice that activists noted was the maldistribution of political economic power in BC. In their view, multinational corporations exercise illegitimate power; they are not citizens, yet they effectively limit the extent to which provincial governments exercise their regulatory authority to protect the environment. ${ }^{67}$ The increasing liberalization of international capital flows exacerbates the situation by adding to the leverage that corporations have over governments. Nearly all the activists saw the power wielded by multinational corporations as unjust, but differed on how to rectify this. Insider preservationists aim to work through government, using popular opinion and rationally designed policy proposals to secure preservation of wild areas. Green egalitarians and civic communitarians work to engage more citizens more fully in politics. Alienated ecocentrics are deeply pessimistic and see hope primarily in disruptive tactics and in refusing to participate in the formal economy. The activists' conception of justice as democratic decision making is evident even in these varying strategies. Each approach aims to increase responsiveness of political economic institutions to the popular will; each reflects a view of how best to organize the power of citizens.

65 In this regard, left-libertarianism and post-materialism capture key elements of the activists' belief systems. See Kanji, "North American Environmentalism," 183-204.

66 See Iris Marion Young's critique of the "distributive paradigm" of justice and argument for a broader notion in which "the concept of justice coincides with the concept of the political" (Justice and the Politics of Difference [Princeton: Princeton University Press, 1990], 34).

67 Only insider preservationists were hesitant to condemn the power of multinational corporations. 


\section{Equality as Sameness}

The environmental movement, like all social movements, frames a set of problems in a manner that promotes collective action to address them. Collective action frames define problems as worthy of public attention and outline means to solve them. ${ }^{68}$ The problem analyses offered by frames must resonate with individuals' experience, requiring that the political ideas upon which collective action frames are constructed be drawn from the broader political culture within which the movement has developed. ${ }^{69}$ Certain beliefs, values and symbols will have cultural weight and/or flexibility. Sidney Tarrow has argued that movement organizers are both "consumers of existing cultural meanings as well as producers of new ones." 70 The activists we interviewed drew on two cultural meanings for justice, fairness as inclusion and equality as sameness.

These values are most evident in activists' perspectives on the role of Aboriginal peoples in environmental management. More specifically, activists tend to agree that First Nations governments should be included in environmental decision making (43) but are wary of treating First Nations different than other communities, reflecting a belief that equal treatment requires treating groups the same as one another. From this perspective, legal equality requires the law to make no distinctions among social groups. It is this conception that underlies the notion of a "colour-blind" society in which citizens and institutions pretend that race, and the legacy of past and present racial prejudices, do not exist. ${ }^{71}$ This notion of equality as sameness, which underlies the contemporary conservative reaction to affirmative action policies, also shapes interviewees' beliefs about the political/legal status of First Nations with regard to natural resource management.

Most interviewees believe that Canadian environmental law should be applied to First Nations, rather than treating them as sov-

68 David A. Snow, E. Burke Rochford, Jr., Steven K. Worden and Robert D. Benford, "Frame Alignment Processes, Micromobilization, and Movement Participation," American SociologicalReview 51 (1986), 464-81.

69 Sidney Tarrow, Power in Movement: Social Movements, Collective Action and Politics (Cambridge: Cambridge University Press, 1994), 120-34.

70 Ibid., 123.

71 For a discussion of how a racialized society might move toward colour-blindness, see Patricia J. Williams, Seeing a Color-Blind Future: The Paradox of Race (New York: The Noonday Press, 1997); and K. Anthony Appiah and Amy Gutmann, Color Conscious: The Political Morality of Race (Princeton: Princeton University Press, 1996). For a discussion of native sovereignty in the context of historical relations between Aboriginals and Canada, see John Borrows, "Re-living the Present: Title, Treaties, and the Trickster in British Columbia," BC Studies 120 (1998-1999), 99-108. 
ereign (17). ${ }^{72}$ Many activists asserted this priority while acknowledging the history of oppression and domination that has characterized the relations between Canada and Aboriginal peoples. They also noted the continued existence of racism in Canadian society and the abysmal economic and social conditions on the reserves. Further, many of the activists voiced their support for native sovereignty and negotiation of native land claims, in principle. These conflicting strands are of course characteristic of people attempting to resolve contradictions among deeply held values. In this case, protecting the environment and equality as sameness seem to conflict with respect for the rights of Aboriginal peoples. Statement 17 reveals this conflict in a very practical context, the application of Canadian environmental law to Aboriginal governments.

Rather than belabour the contradiction (and the difficulties it poses for building productive relations between non-Aboriginal environmentalists and Aboriginal governments), an alternative approach is to reframe the question. In response to statement 17 , one of the activists noted: "There is a difference between the kind of laws that First Nations operate under and the laws made by bureaucrats in Ottawa. It's not about making First Nations conform to colonial law." This formulation makes explicit the inequality that characterizes the relations between Canadian governments and First Nations governments. It also recognizes two co-existent nations. Implicit in this statement is a conception of fairness that permits groups to be treated differently. Indeed, Canadian political culture offers resources that challenge the conflation of fairness and sameness. The long struggles to address the autonomy claims of both Aboriginal peoples and French Quebeckers have created the bases for group rights and differentiated citizenship in Canada. ${ }^{73}$ The Canadian constitution recognizes and protects language rights of French and English linguistic minorities and treaty rights of Aborigi-

72 Green egalitarians are the exception here as they tended to support native sovereignty both in principle and in relation to specific aspects of environmental management.

73 For extended discussions of group rights and sovereignty issues, see Simone Chambers, Reasonable Democracy: Jürgen Habermas and the Politics of Discourse (Ithaca: Cornell University Press, 1996), 212-27; Will Kymlicka, "Three Forms of Group-Differentiated Citizenship in Canada," in Seyla Banhabib, ed., Democracy and Difference: Contesting the Boundaries of the Political (Princeton: Princeton University Press, 1996), 153-70; and Charles Taylor, Reconciling the Solitudes: Essays in Canadian Federalism and Nationalism (Montreal: McGill-Queen's University Press, 1993). 
nal peoples. Group rights are intended to protect distinct collective identities by limiting the group's vulnerability to the political and economic power of the larger society. ${ }^{74}$

\section{Conclusion}

One must exercise caution in generalizing from a sample of 46 individuals. Indeed, our intent here is not to make inferences about the distribution of particular worldviews within the population of BC environmental activists, but to classify political perspectives within the province's environmental movement. Like all classification exercises, this involves creation of a structure (the four perspectives arrayed along two dimensions) to organize the various ideas expressed by participants in the movement. Other analysts might settle on a different set of categories. The structure that has emerged from this analysis is useful in identifying perspectives on social justice and democracy within the $\mathrm{BC}$ environmental movement. Moreover, understanding of these perspectives is crucial to understanding relations between the environmental movement and other progressive sectors. As evidenced by the Green party performance in the 2001 provincial election, relations between these sectors will continue to influence electoral outcomes.

For most of the activists, justice is about fair democratic processes, and fairness requires treating all citizens and groups the same. More generally, interviewees' ideas about justice focused on democracy and fair procedures. The activists' conception of justice as a procedural issue of democratic governance is consistent with Habermas' description of new politics. ${ }^{75}$ It is this conception that provides the answer to the question: What does social justice mean for environmentalists and how will their understandings of justice affect their relations with other progressive movements?

The activists' lack of focus on redistribution and their belief in equality as sameness are problematic in this regard. These values are not particularly congruent with the priorities of the $\mathrm{BC}$ labour movement; nor are they likely to support sturdy coalitions with Aboriginal people. But the activists' focus on broadly distributing power to advance democracy may hold promise for linking the environmental movement to other progressive movements. Because environmentalists are democracy-seeking, they occupy common political space with

74 Will Kymlicka, "Citizenship and Identity in Canada," in James Bickerton and Alain-G. Gagnon, eds., Canadian Politics (3rd ed.; Peterborough: Broadview, 1999), 19-38.

75 Habermas, "New Social Movements," 32-37. Though, again, insider preservationists are an exception; broad-based participation is not a priority for them. 
other justice-seeking groups, and with both the old politics of class and the new politics of identity. Out of this mix may come a common conception of justice based on equality, not as sameness, but as recognition of, and sensitivity to, difference. The Canadian political tradition offers the cultural resources to support this conception of justice. Work with other progressive movements, especially Aboriginal people, will be facilitated as the environmental movement achieves greater self-consciousness of itself, and those outside the movement gain a clearer understanding of the complexity of environmentalists' political beliefs and values.

\section{Appendix: Statements and Factor Scores}

\begin{tabular}{l} 
Statements \\
\hline 1. I believe that God created the world and every- \\
thing in it. We people were given the responsibil- \\
ity to look after it. \\
2. The solution is for people to by-pass government \\
and industry. To say actually, "No, I don't think \\
trans-national free trade is what I want to govern \\
my life. I'm going to shop locally. Im going to \\
promote the economy of my area."
\end{tabular}

3. There's nothing wrong with a person making money and a corporation has to make profit. Corporations are great employers of people. Some corporations may be detrimental to the environment; other corporations might be detrimental to people. But they have to be there.

4. What is left to us is to keep kicking at the knee caps of whomever we can and talking to anybody that we can to say the structure of the society that we live in is fundamentally crazy.

5. I don't see Canada as a viable entity. It's much too big. Even the provinces are massive. I'm a big fan of regionalization, bringing things down to the local level.

6. People don't like to be legislated; they like some freedom. If you educate people about the value of the environment, then they're more likely to protect it than they would if there were just a law.

\begin{tabular}{cccc}
\multicolumn{4}{c}{ Factor Scores } \\
AE & CC & IP & GE \\
-5 & +5 & -1 & -3
\end{tabular}

$\begin{array}{llll}+3 & +1 & -2 & +3\end{array}$

$\begin{array}{llll}-5 & -2 & 0 & -4\end{array}$

$\begin{array}{llll}+1 & -3 & -4 & -2\end{array}$

$\begin{array}{llll}-3 & -3 & -4 & -1\end{array}$

$\begin{array}{llll}0 & +2 & -1 & -1\end{array}$ 
7. First World environmentalism has to start connecting with Third World social problems. You think you're just stopping the pesticide spraying on the river and suddenly you're in touch with women who are being poisoned in Third World countries using these very same pesticides that have been banned in our country.

8. Environmental wealth is not distributed evenly from one neighbourhood to another. Poor neighbourhoods with high numbers of Chinese and Punjabi people do not get park space within Vancouver. This is an environmental issue, a class environmental issue.

9. I feel like our decentralized environmental movement, and the variety of ways that we work, are really a strength.

10. What we have to do is organize. Politicians are like wind vanes. You don't talk them into changing directions, you have to blow in their face.

11. When you cut the forests down you wreck the streams, you lose the fish and the animals and the birds and the insects. The whole system depends on the forest. It's very hard to separate out any part of the chain.

12. The unfortunate thing is that rich countries are the least affected because we're rich so we can buy our way out, either with another technology or we somehow manage because we're rich. The rich in every country will be okay. But there will be pockets in the world where it will be pretty homible.

13. I really don't see humans as being all that more important than all the other creatures on the earth. Sometimes in my more cynical moments I think the world would be happier off without us. Let the sea lions take over.

14. There are no such things as the US and Canada any more. When you have the World Trade Organization and NAFTA, which are actually governments or government processes, then you don't have national governments that can make laws and implement them.

$\begin{array}{llll}-1 & -4 & -1 & +2\end{array}$

$\begin{array}{llll}0 & 0 & -1 & +1\end{array}$

$\begin{array}{llll}+1 & -1 & +3 & +2\end{array}$

$+4+4+4 \quad+4$

$\begin{array}{llll}-1 & -2 & +4 & -1\end{array}$

$\begin{array}{llll}+2 & 0 & -3 & -2\end{array}$

$\begin{array}{llll}+1 & -3 & -3 & 0\end{array}$ 
15. That's one difference between the US and $\begin{array}{llll}-4 & -1 & -2 & -5\end{array}$ Canada; Canadians are more apathetic in terms of political involvement than people in the US.

16. Im trying as much as possible to be pro-business, in the sense that I have to understand that people need to work. Strong communities are built on full employment.

17. People care about First Nations and want resolution to the land claims. But should First Nations be exempt from the Canadian Environmental Assessment Act? That isn't fair. Why should anybody be exempt?

18. Here we are at a period of history where, on the whole, in the developed world, our lives are more comfortable. What the environmental movement is saying is, "You're all far too comfortable, and you need to give a lot of things up now." It's not exactly the premise that you can start a very revolutionary movement on.

19. My son is one of the main reasons that $I$ am an environmentalist. I got to know a forest, and wild salmon, and all of that and I want him to be able to have that experience.

20. For me the environment has to come first. If it's a question between a job or an environment that is going to be degraded, then that environment comes first.

21. Civil disobedience is the only tactic that has really made a difference.

22. I believe in private land ownership, but I think there should be more regulations regarding the stewardship of that land and the responsibility attached to that.

23. Say jobs, jobs, jobs three times quickly and people will tum around and walk away while you cut a forest down. You don't have to be a genius to know that those jobs, jobs, jobs are going to be gone, gone, gone permanently once those trees are gone.

24. As a wilderness area becomes more popular, you need public washrooms, or johnny-on-thespots, you need to control where people camp. So it has to be managed, and it's only fair that the user should pay.

$\begin{array}{llll}+2 & +2 & +3 & 0\end{array}$

$\begin{array}{llll}-3 & -2 & -2 & +2\end{array}$

$\begin{array}{llll}0 & +3 & -3 & +1\end{array}$

$\begin{array}{llll}+5 & +3 & +2 & +1\end{array}$

$\begin{array}{llll}-2 & -5 & -4 & -4\end{array}$

$\begin{array}{llll}-1 & 0 & +4 & +1\end{array}$

$\begin{array}{llll}+2 & +1 & +5 & +2\end{array}$

$\begin{array}{llll}-2 & 0 & -2 & -1\end{array}$ 
25. Im leaning toward voting for the Green party.

26. If you're going to talk to a governmental official you've got to try and give facts. You have to communicate on a level that planners and bureaucrats will understand.

27. I am not a stakeholder, I don't have any personal interest in this at all. This is about protecting the environment, not dividing up the pie.

28. Courts work on law, so if you have a law then you can go to court. Until we have that I think we're just going to be getting involved in processes that wear us out while they destroy the environment.

29. I think the timber industry is still important. It's not like we should eliminate the timber industry.

30. Tourism has negative impacts on community cohesion in small towns. You often see towns that are touristy and a lot of families that have been there for a long time don't benefit from tourism.

31. The developers love the First Nations' land. They can go and do what they like. It's a real opportunity to exploit and why wouldn't they?

32. Environmentalism is about community, a community of animals, a community of water users, a community of workers. Ultimately that's the challenge of the future.

33. I don't think that you should turn around and say, okay we need affordable housing, let's put a whole bunch of houses in Seymour, on the mountain. I would rather keep it unaffordable, to protect that mountain and protect that ocean and protect those trees and protect the reason we all live here. I would rather move away and protect it than be able to afford to live here and ruin it.

34. If you're physically destroying my environment, you're cutting down these trees, causing landslides, causing erosion, washing out streams where my fish are, I feel I have a right to physically stop you. You are physically destroying my world.

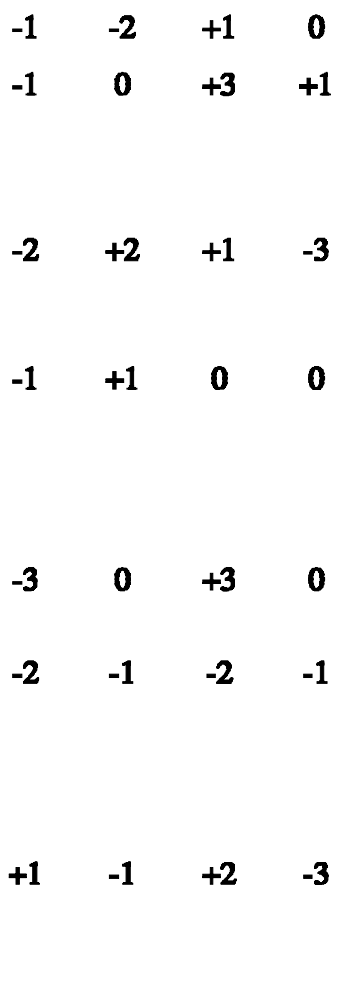

$\begin{array}{llll}0 & +5 & +5 & +5\end{array}$

$\begin{array}{llll}0 & 0 & -1 & -2\end{array}$

$\begin{array}{llll}+5 & -1 & -5 & +1\end{array}$ 
35. I concentrate on people, because I am a person $\begin{array}{llll}-3 & -2 & -1 & -3\end{array}$ myself and most of my friends are people. I think it has to do with scale and at a local scale people take priority. At a larger scale, like a global scale, then plants and animals have more priority.

36. I think an environmentalist is somebody who gives a shit and is willing to let people know that they give a shit. It is somebody who takes action to participate in their society on matters of ecological importance.

37. Im absolutely disgusted with the IWA. They show no morality at all. They are just flunkies who protect the corporations' right to get the wood, because in that case they get a job.

38. I realize just how intertwined environmental issues and social justice issues are. It is not possible to properly deal with environmental issues without looking at social injustice as a foundation for a lot of the envirommental exploitation that goes on.

39. Bureaucrats stay the same and politicians move on; bureaucrats run the show. They dictate what happens in government.

40. Im optimistic that we can become more sophisticated in being able to present alternatives, not just say that everything else be damned.

41. When I think about environment, I think green and I guess what that really means is that Im thinking about ecologically intact systems. I automatically think of the wilderness and ecological issues.

42. I have learned that it really doesn't matter which political party is in government.

43. You cannot protect the land without including First Nations. It isn't just recognition of title, but inclusion in all the work you do, giving them a place at every table, making sure that their place at the table is recognized, that their concerns are addressed.

44. I'd rather see fewer people born and everyone have a good life, than billions of people on the planet, some of whom live and die literally on garbage heaps.

$\begin{array}{llll}-2 & -4 & +2 & -2\end{array}$

$\begin{array}{llll}+3 & +2 & -2 & +5\end{array}$

$\begin{array}{llll}-1 & -1 & -3 & 0\end{array}$

$\begin{array}{llll}-2 & +1 & +2 & +3\end{array}$

$\begin{array}{llll}0 & +4 & 0 & -2\end{array}$

$\begin{array}{llll}+3 & -2 & -3 & -1\end{array}$

$+2+3 \quad+1 \quad+4$

$\begin{array}{llll}+1 & -3 & +2 & -4\end{array}$ 
45. Politicians have very strong views until they see

five hundred voters show up at a public meeting and then they'll sell their Grandmother. I mean they'll change a hundred and eighty degrees overnight. Why? Because their number one job is to get re-elected.

46. I really don't agree with designating parks; they exclude interactions of people and the land.

47. I like the idea of the old town meeting, where everybody went once a month to discuss subjects of general interest to the commumity. My political philosophy is that community is very important and we should all be involved.

48. I live in a rural area and Im not there to make enemies. We've tried to keep most of our environmentalism within this area, this community. It's easy to go in, canse a lot of disturbance, leave, and that's it. But our kids still have to live here, our neighbours are still those same people.

49. We have to take responsibility for democracy. We can't rely on others, politicians and bureaucrats, making those decisions for us, because they don't know any more than we do.

50. Im proud of being an environmentalist. One of the things that the right wing has tried to do is smear us. As far as I'm concerned, you can call yourself what you want, a conservationist, preservationist, whatever, but Im an environmentalist.

51. I think the planet's going down hill-I don't think we have enough self-control, intelligence, or the wisdom to stop.

52. Tve been getting more and more cynical and bleak in my assessment of electoral politics and the relationship between politics and the economy. I see more and more clearly how with NAFTA and GATT, the corporations have won the day in the sense that now corporations have legal control over governments at every level. And that makes me want to just tear up my ballot and my voter's registration card, or vote Rhinoceros, really.

$\begin{array}{llll}+3 & +2 \quad+1 \quad+4\end{array}$

$\begin{array}{llll}+1 & +1 & 0 & -1\end{array}$

$\begin{array}{llll}+2 & -5 & +1 & -5\end{array}$

$+1 \quad-4 \quad 0 \quad-2$ 
53. The way it's structured right now you have this cut and ron mentality where the company comes in and takes most of the resources and then goes off somewhere else. Because they're multinational they can do that.

54. To me feminism and environmental things are extremely closely related. The brutalization of nature and the brutalization of women are part of the same package.

$+4 \quad+2 \quad+3 \quad+3$

$\begin{array}{llll}0 & -3 & 0 & +2\end{array}$ 